\title{
The Role of Profit Sharing in a Dual Labour Market with Flexible Outsourcing
}

\author{
ERKKI KOSKELA \\ JAN KÖNIG
}

CESIFO WORKING PAPER NO. 2533

CATEGORY 4: LABOUR MARKETS

JANUARY 2009

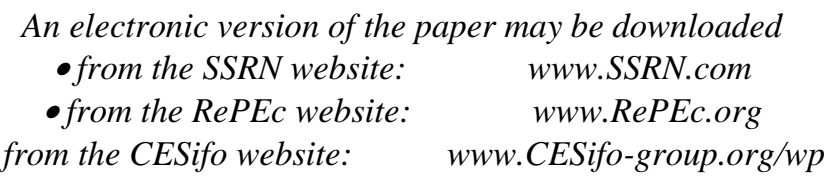




\title{
The Role of Profit Sharing in a Dual Labour Market with Flexible Outsourcing
}

\begin{abstract}
We analyze the following questions associated with flexible outsourcing under partly imperfect dual domestic labour markets, where high skilled workers participate in firm's profit via profit sharing: How does the implementation of profit sharing influence flexible outsourcing? What is the relationship between outsourcing cost, profit sharing and wages? We show that profit sharing has a positive effect on low skilled wage and thus an outsourcing enhancing character. The wages of both types of labour are negatively correlated and lower outsourcing cost can increase the wage dispersion by decreasing the low skilled wage and raising the high skilled wage. The overall effect of profit sharing on high skilled wage is ambiguous due to a positive direct effect and a negative indirect effect via the low skilled wage.
\end{abstract}

JEL Code: E23, E24, H22, J23, J51, J82.

Keywords: flexible outsourcing, dual labour market, profit sharing, labour market imperfection, employee effort.

\author{
Erkki Koskela \\ Department of Economics \\ University of Helsinki \\ P.O. Box 17 (Arkadiankatu 17) \\ 00014 Helsinki \\ Finland \\ erkki.koskela@helsinki.fi
}

\author{
Jan König \\ School of Business and Economics \\ Free University Berlin \\ Boltzmannstrasse 20 \\ 14195 Berlin \\ Germany \\ jan.koenig@fu-berlin.de
}

We thank seminar participants at the FU Berlin for their comments. The authors thank the Research Unit of Economic Structures and Growth (RUESG), financed by Academy of Finland, University of Helsinki, Yrjö Jahnsson Foundation, Bank of Finland and Nokia Group, for financial support. Koskela also thanks Academy of Finland (grant No. 1117698) and König thanks RUESG for great hospitality. 


\section{Introduction}

In an integrated world, marginal cost differences are the driving force for the reallocation of production parts (offshoring) and for the make-or-buy-decision (outsourcing). Especially for western European countries, the wage and labour cost differences constitute the central explanation for the increasing business practice of offshoring and international outsourcing to eastern European or Asian countries. ${ }^{1}$ Reasons for the wage gaps are, among others, differences in labour market institutions and in the process of wage determination. In most western European countries, wages are determined by bilateral bargaining between firms or employer federations and trade unions. In eastern European or Asian countries, however, unions are much weaker so that wages are determined by market forces. Typically low-skilled workers in western Europe are unionized so that labour unions are able to push for their relatively high wages at the cost of a higher unemployment in continental Europe than in the United States (see e.g. Freeman and Schettkat (2001)). In opposite to the low skilled, wages of skilled workers are mostly determined competitively. ${ }^{2}$

Since western European firms have the opportunity to buy foreign intermediate goods after knowing the domestic wage levels and so the marginal production cost, this will affect the domestic wage formation process for both types of workers. The threat of flexible outsourcing as a reaction to high domestic marginal production cost will dampen the opportunity of the trade union to realize a high wage level for the low skilled. To induce them to abstain from external procurement of intermediate goods, western European firms need lower marginal cost. Since both, wages for skilled and unskilled, affect the marginal production cost, there are two components to reduce marginal cost. If lower wages are not possible, firms have to raise their productivity.

1 See Amiti and Wei (2005) and Rishi and Saxena (2004), which emphasize the big difference in labour costs as the main explanation for the strong increase in outsourcing of both manufacturing and services to countries with low labour costs.

2 There are some papers that analyze the effects of outsourcing when labour is heterogeneous, like Davidson et al. (2007) and Davidson et al. (2008). However, these papers concentrate on labour market frictions that arise with search, while we focus on the role of labour unions in the case of unskilled wage formation. 
One channel to increase productivity is to stimulate workers' effort. The firm may introduce a profit sharing scheme that lets workers participate in the firm's success. The implementation of profit sharing will induce incentives to increase effort and thus productivity for given wage levels. Empirical studies show that profit sharing is an important phenomenon in many OECD countries. Pendleton et al. (2001) have presented detailed data on profit sharing schemes in 14 OECD countries. ${ }^{3}$ However, only high skilled workers, such as managers, often realize profit sharing as a part of their income. So they participate in the firm's success, which is positively influenced by their effort. But profit sharing will also affect wage formation for low and high skilled workers. Since a part of the wage income can be substituted by profit income, profit sharing can probably affect the base wage for the high skilled workers. Although higher effort of skilled workers provides higher productivity and thus raises the firm's profit, which opens the opportunity for the trade union to pick up a higher share of this profit by demanding a higher wage for low skilled workers. However, this dampens the advantage of domestic production and increases outsourcing activities. As profit sharing is now commonly incorporated in the compensation schemes and international outsourcing has recently increased, e.g. in western EU-countries and in the United States, it is important to study the implications of profit sharing and wage bargaining on flexible outsourcing in a partly dual labour market.

Concerning the analysis of the effects of outsourcing on compensation schemes under wage bargaining, there are two focuses in the literature, the case of committed and flexible outsourcing. While in the committed case outsourcing takes place before wage bargaining ${ }^{4}$, in the flexible case outsourcing is decided after wage bargaining. Our focus in this paper is to assume that outsourcing is flexible, i.e. determined

See also Conyon and Freeman (2001).

See e.g. Perry (1997) for an overview about the relationship between outsourcing and wage bargaining. Also e.g. Danthine and Hunt (1994) and Zhao (1998, 2001) have studied the effects of international outsourcing and foreign direct investment on wage formation in the home country. They showed that higher product market integration implies intensified product market competition, which moderates wage increases in unionized labour markets. Skaksen and Sorensen (2001) have studied the effects of trade unions on firms' foreign direct investments, which are made prior to the stage of the wage bargaining. Lommerud et al. $(2006,2009)$ have presented a theoretical model with monopolistic and oligopolistic competition to determine how unionization affects the fraction of outsourced inputs. 
simultaneously with domestic labour demand, but after wage formation for low skilled workers. To our knowledge, the first one, who studied the effects of flexible outsourcing on wage setting, is Skaksen (2004). ${ }^{5}$ Also, Braun and Scheffel (2007b) have developed a simple two-stage game between a monopoly union and a firm by assuming that the labour union sets wages before the firm decides on the degree of outsourcing. But in these papers they have abstracted from the analysis of profit sharing as a part of the compensation scheme or heterogeneity of labour force, which is our focus. ${ }^{6}$ Concerning the wage effect of profit sharing, Koskela and Stenbacka (2006) have studied the differences between committed and flexible profit sharing, but both in the absence of outsourcing and heterogeneous labour market.

An analysis on the interaction of different profit sharing schemes and outsourcing, in strategic (committed) and flexible case, is done by Koskela and König (2008a, 2008b). However they also focus on homogenous labour force. We extend their work by allowing for two types of workers $^{7}$ in dual labour markets by providing answers to the following question: How does the implementation of profit sharing for high skilled workers influence outsourcing activities? By analyzing our main question, we thus also find answers to: How do the opportunity of flexible outsourcing and its cost influence the wage for both types of workers and profit sharing? And, what is the relationship between profit sharing and wage levels? We analyze these questions in a partial equilibrium model in which we assume a time sequence of the profit sharing decision, where firms commit to profit sharing before the base wage formation.

5 He has analyzed the implications of outsourcing, in terms of both potential (non-realized) and realized international outsourcing, for wage setting and employment under imperfectly competitive labour markets.

$6 \quad$ There are also some new analyses, which incorporated flexible outsourcing and wage bargaining, e.g. Koskela and Poutvaara (2008b), Koskela and Schöb (2008) or Koskela (2008). But the main focuses in these papers are labour taxation issues in the absence of profit sharing and in Koskela and Schöb (2008) and Koskela (2008) also in the absence of worker heterogeneity.

7 Koskela and Stenbacka (2007) analyze strategic outsourcing in a dual labour market in the presence of wage solidarity by the labour union. Analyzing strategic outsourcing in a dual labour market is also done by Koskela and Poutvaara (2008a), but they are interested in taxation effects in the absence of profit sharing. For an introduction into the debate on dual labour markets, see Saint-Paul (1996). His focus is on dual labour market with identical workers by looking on the dynamic efficiency wage models, but there is also a part with heterogeneous workers. However, this research is also in the absence of both outsourcing and profit sharing. 
We find that in this case, the wage of the high skilled will be negatively affected by the wage of the low skilled. For the effect of implementing committed profit sharing we show, that it will have a direct effect on the skilled wage, which has a supplementary character, but a negative indirect effect via the effect on the wage for the low skilled worker. Thus the overall effect on high skilled wage is ambiguous. Since the firm is flexible to decide about the amount of outsourcing after decisions are made concerning wage negotiation for the low skilled and profit sharing for the high skilled, these income parts are influenced by outsourcing costs. We find that in this case lower outsourcing cost leads to falling wages for the low skilled. Since the high skilled wage does not directly depend on outsourcing cost, thus the high skilled wage is only affected indirectly via low skilled wage. Here, lower outsourcing cost will increase the high skilled wage and will thus raise the wage dispersion. Given that outsourcing demand is only affected by the relation of low skilled worker wage and outsourcing cost, profit sharing will have an enhancing indirect effect on outsourcing activities.

Due to globalization and the increasing opportunity of outsourcing existing jobs can be eliminated. ${ }^{8}$ We try to give an answer to: Is profit sharing to high skilled workers while unions bargaining over low skilled wage an instrument that can avoid outsourcing and secure existent jobs. If the answer is "yes" and politicians are interested in job security, they should set any incentives to the firm to implement a profit sharing scheme for high skills. In the opposite case, the incentives should be cut profit sharing schemes for high skills. With our result we can also give a suggestion if politicians have two aims: job security for low skills and decreasing wage dispersion. In this case we would conclude that policy should, again, set incentive to prevent profit sharing for high skills and uses its power to increase the cost of outsourcing.

We proceed as follows. Section II presents the basic structure of theoretical framework and two different time sequences in terms of profit sharing decision. Labour demand, outsourcing and employee effort and skilled wage formation are presented in Section III. Section IV investigates the low skilled wage formation by monopoly labour union with committed profit sharing. Finally, we present conclusions in section V.

From the efficiency point of view that may be preferable, politicians may be interested to save these existent jobs due to market intervention. 


\section{Basic Framework}

We analyze a model with heterogeneous domestic workers, i.e. dual domestic labour market, flexible international outsourcing and committed profit sharing. The production combines labour services by effective skilled workers and unskilled workers. Effective skilled employment is a combination of absolute skilled employment and the effort by skilled workers, i.e. their productivity. Following empirical studies, we assume that low skilled workers and outsourcing activities are substitutes, so that unskilled labour services can be provided either by the firm's own workers, or obtained from abroad through international outsourcing. We assume that the firm may be flexible enough to decide upon the amount of outsourcing activity after the wage for low skilled worker is set by the labour union. The analyzed timing decision is summarized in Figure 1. The timing structure captures the idea that the representative firm decides profit sharing before the monopoly trade union sets the unskilled wage.

Figure 1: time sequences of decision

Flexible outsourcing and committed profit sharing

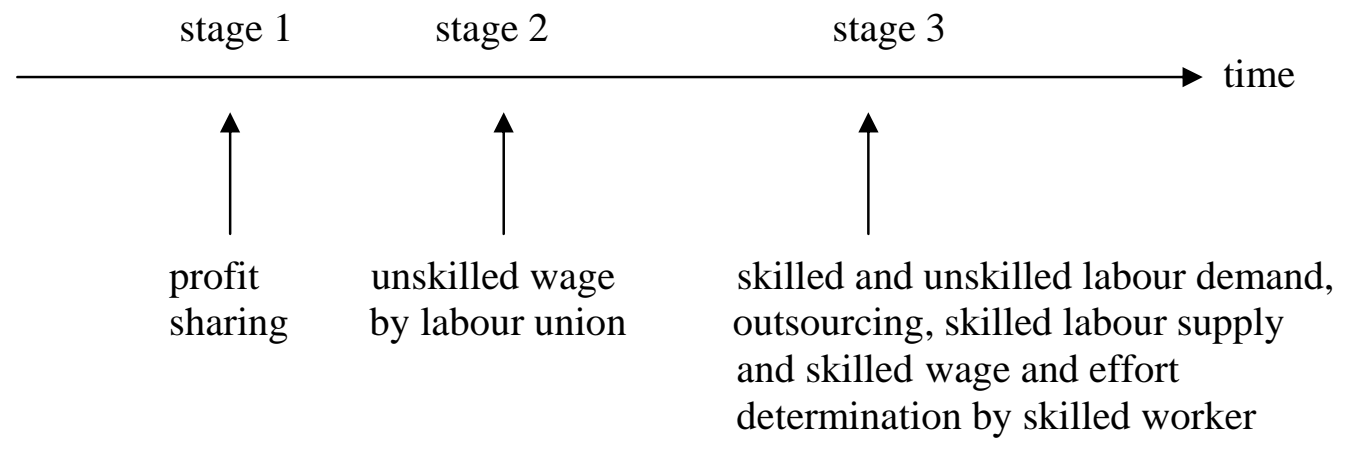

In this timing structure profit sharing is assumed to be committed at stage 1 and at stage 2 conditional on profit sharing, the labour union determines the wage for the 
unskilled workers by taking into account how this affects the demand for labour and outsourcing by the firms. We assume that there are many industries, so that each labour union represents only a small fraction of the total labour force. At stage 3, firms decide on domestic employment and international outsourcing. The wage of the skilled labour adjusts to equalize labour demand and labour supply and, moreover, the representative skilled worker decides on effort provision. The decisions at each stage are analyzed by using backward induction.

\section{Labour Demand, Outsourcing Decision, Employee Effort and Skilled Wage Formation}

\section{III.1. Labour Demand and Outsourcing}

At the last stage, the representative skilled worker decides on the effort $e$ and the representative firm decides on the skilled labour demand $H$, the unskilled labour demand $L$, and outsourcing $M$. The firm decides domestic labour demand and outsourcing to maximize the profit function

$$
\underbrace{\operatorname{Max}}_{(H, L, M)} \pi=F(e H, L, M)-w_{H} H-w_{L} L-g(M)
$$

by taking the skilled worker's effort, $e$, the negotiated unskilled and skilled wages, $w_{L}$ and $w_{H}$, as well as profit sharing, $\tau$, as given. In order to obtain $M$ units of outsourced unskilled labour input, we assume that firms also have to spend $g(M)=0,5 c M^{2}$ with $g^{\prime}(M)=c M>0$ and $g^{\prime \prime}(M)=c>0$. This increasing marginal cost of outsourcing captures the idea that there are some other costs associated with outsourcing as the price for the intermediate goods. Such cost could be communication cost or cost for quality proofing.

In case of our production function, we partly follow Koskela and Stenbacka (2007) by assuming a general and reasonable Cobb-Douglas-type production function 
with decreasing returns to scale according to three labour inputs, i.e. $F(e H, L, M)=\left[(e H)^{a}(L+M)^{1-a}\right]^{\rho}$, where the parameters $\rho$ and $a$ are assumed to satisfy the assumption: $0<\rho ; a<1$. From (1) we can derive the marginal products of skilled labour, unskilled labour and outsourcing: $F_{H}=\rho Y^{\rho-1} a e^{a} H^{a-1}(L+M)^{1-a}$ and $F_{L}=\rho Y^{\rho-1} e^{a} H^{a}(1-a)(L+M)^{-a}=F_{M}$, with $Y=(e H)^{a}(L+M)^{1-a}$. The outsourced unskilled labour input affects the marginal products of the domestic skilled and unskilled labour inputs as follows:

$$
F_{H M}=\rho^{2} Y^{\rho-1} a e^{a} H^{a-1}(1-a)(L+M)^{-a}>0
$$

and

$$
F_{L M}=-\rho Y^{\rho-1}(e H)^{a}(1-a)(L+M)^{-a-1} \underbrace{1-\rho(1-a)]}_{+}<0 .
$$

Taking these, we can conclude that for our type of production function the domestic skilled labour input and the outsourced unskilled labour input are complements, whereas the unskilled domestic labour input and the outsourced unskilled labour input are substitutes in terms of the marginal product effects of outsourcing. ${ }^{9}$ Also, one can calculate from the production function that the domestic skilled and unskilled labour are complements, i.e. $F_{H L}=\rho^{2} Y^{\rho-1} a e^{a} H^{a-1}(1-a)(L+M)^{-a}>0$. Using the marginal products we can calculate the first-order conditions characterizing the domestic skilled and unskilled labour demand and outsourcing activities

$$
\begin{aligned}
& \pi_{H}=\frac{\rho a}{H} F-w_{H}=0 \\
& \pi_{L}=\frac{\rho(1-a)}{(L+M)} F-w_{L}=0
\end{aligned}
$$

Ethier (2005) has introduced a partly related production function to analyze the decision between international outsourcing and in-house production for analyzing the effect of globalization on the skill premium. 


$$
\pi_{M}=\frac{\rho(1-a)}{(L+M)} F-c M=0
$$

These first-order conditions (2a) and (2b) imply the relationship between the skilled $(H)$ and the unskilled labour inclusive of outsourcing $(L+M)$ as follows

$$
H=\frac{w_{L}}{w_{H}} \frac{a}{1-a}(L+M) .
$$

Using (2b) and (2c) we get the demand for outsourcing as

$$
M=\frac{w_{L}}{C},
$$

where $\frac{M_{w_{L}} w_{L}}{M}=1$, and $-\frac{M_{c} c}{M}=1$. According to equation (4) higher unskilled domestic wage rate and lower outsourcing cost will increase outsourcing.

Substituting the RHS of (3) into (2b) gives the unskilled labour demand, which can be expressed as follows (see Appendix A)

$$
L=m w_{L}^{-\delta} w_{H}^{-\varepsilon} e^{\varepsilon}-M=m w_{L}^{-\delta} w_{H}^{-\varepsilon} e^{\varepsilon}-\left(\frac{w_{L}}{c}\right),
$$

where $m=\left[\rho a^{a \rho}(1-a)^{1-a \rho}\right]^{\frac{1}{1-\rho}}>0, \delta=\frac{1-\rho a}{1-\rho}>1$ and $\varepsilon=\frac{\rho a}{1-\rho}>0$, with $\delta$ as the own wage elasticity and $\varepsilon$ as the cross wage elasticity in the absence of outsourcing. According to (5), a more extensive outsourcing activity will decrease the unskilled labour demand, which shows again the substitutability of low skilled labour and international outsourcing, which is consistent with empirical evidence. As we can see, higher own wage and cross wage and lower high skilled effort will affect negatively the unskilled labour demand. In the presence of outsourcing the wage elasticities of the 
unskilled labour, $-\left.\frac{L_{w_{L}} w_{L}}{L}\right|_{M>0}=\eta_{L}$ and $-\left.\frac{L_{w_{H}} w_{H}}{L}\right|_{M>0}=\eta_{H}$, and the effort elasticity of the unskilled labour $\left.\frac{L_{e} e}{L}\right|_{M>0}=\eta_{e}$ can be written as follows

$$
\begin{aligned}
& \eta_{L}=\delta\left(1+\frac{M}{L}\right)+\frac{M}{L}=\delta+(1+\delta) \frac{M}{L}=\delta+(1+\delta) \frac{w_{L}}{c L} \\
& \eta_{H}=\varepsilon\left(1+\frac{M}{L}\right)=\varepsilon\left(1+\frac{w_{L}}{c L}\right)=\eta_{e} .
\end{aligned}
$$

Of course, in the absence of outsourcing both the wage and effort elasticities are constant and smaller, i.e. $\left.\eta_{L}\right|_{M=0}=\delta$ and $\left.\eta_{H}\right|_{M=0}=\left.\eta_{e}\right|_{M=0}=\varepsilon$.

Using the wage elasticities (6a) and (6b) we find that $\frac{\partial \eta_{L}}{\partial M}=\frac{(1+\delta)}{L}\left(1+\frac{M}{L}\right)>0$ and $\frac{\partial \eta_{H}}{\partial M}=\frac{\varepsilon}{L}\left(1+\frac{M}{L}\right)=\frac{\partial \eta_{e}}{\partial M}>0$ so that when outsourcing will increase, the own wage and cross wage elasticities of the unskilled labour demand increase. These are also in conformity with empirical evidence. The effects of outsourcing cost on the own wage and the cross wage elasticity of unskilled labour are

$$
\begin{aligned}
& \frac{\partial \eta_{L}}{\partial c}=(1+\delta) \cdot\left[\frac{\left(L M_{c}-M L_{c}\right)}{L^{2}}\right]=-(1+\delta) \frac{M}{c L}\left(1+\frac{M}{L}\right)<0 \\
& \frac{\partial \eta_{H}}{\partial c}=\varepsilon \cdot\left[\frac{\left(L M_{c}-M L_{c}\right)}{L^{2}}\right]=-\varepsilon \frac{M}{c L}\left(1+\frac{M}{L}\right)=\frac{\partial \eta_{e}}{\delta c}<0
\end{aligned}
$$

so that lower outsourcing cost will increase the wage elasticities of domestic unskilled labour demand. ${ }^{10}$

10 See e.g. Hasan et al. (2007), Slaughter (2001) and Senses (2006), who have provided empirical evidence according to which international trade has increased the wage elasticity of low-skilled labour demand. 
Finally, substituting the RHS of equation (5) into the relationship in equation (3) gives the following labour demand for the representative skilled worker

$$
H=\frac{m a}{1-a} w_{H}^{-(1+\varepsilon)} w_{L}^{-(\delta-1)} e^{\varepsilon},
$$

where $(1+\varepsilon)=-\frac{H_{w_{H}} w_{H}}{H}=\frac{1-\rho(1-a)}{1-\rho}>1,(\delta-1)=-\frac{H_{w_{L}} w_{L}}{H}=\frac{\rho(1-a)}{1-\rho}>0$ and $\varepsilon=\frac{\rho a}{1-\rho}>0$. These elasticities are also higher with weaker decreasing returns to scale, but unlike in the case with unskilled labour, both the own wage and cross wage labor demand elasticities and the effort elasticity for the skilled labour are independent of outsourcing. As for unskilled demand, higher own wage, cross wage and the lower effort will of course affect negatively the skilled labour demand.

We can now summarize our findings of an asymmetry in how the demands for skilled and unskilled labour react to the cost of outsourcing as follows.

Proposition 1: In the presence of flexible outsourcing

(a) the own wage, the cross wage and the effort elasticity for the unskilled labour demand depend negatively on the cost of outsourcing, and positively on the amount of outsourcing, whereas

(b) the own wage, the cross wage and the effort elasticity for the skilled labour demand are independent of the cost of outsourcing.

\section{III.2. Wage Formation for Skilled Workers}

\section{III.2.1 Optimal Labour Supply and Effort Determination of Skilled Workers}

We assume that the market equilibrium for the skilled wage $w_{H}$ follows from the equality of labour demand and the labour supply. The high skilled labour supply is 
assumed to be constant, i.e. $H^{s}=\mu{ }^{11}$ Taking this assumption into account, we derive the high skilled wage from market equilibrium by taking the low-skilled wage $w_{L}$ as given.

The effort determination of the skilled worker is assumed to be determined as follows: The effort provision of the skilled worker is associated with a disutility, which is assumed to satisfy the function $h(e)=\gamma e^{1 / \gamma}$ with $0<\gamma<1$ so that it is convex, $h^{\prime}(e)=e^{(1 / \gamma)-1}>0 h^{\prime \prime}(e)=[(1 / \gamma)-1] e^{(1 / \gamma)-2}>0$. Under constant labour supply the overall utility only depends on the profit income and the disutility of effort as the difference between profit income and the sum of disutility of effort $S=\tau \pi-H \cdot h(e)$. We assume identical high skilled worker, so that the individual utility function for the employed high skilled worker in terms of profit sharing, firm's profit and disutility of effort can be written as

$$
U=\frac{S}{H}=\tau \frac{\pi}{H}-h(e),
$$

where $\tau$ is profit sharing and $\pi$ the representative firm's profit. Equation (9) shows that every skilled worker gets the same per capita profit income, but he/she realizes the individual disutility for providing a certain effort level. The optimal individual provided effort level results from individual utility maximization of (9) with respect to effort, which yields the first-order condition

$$
U_{e}=\frac{\tau}{H} \pi_{e}-h^{\prime}(e)=0
$$

Using $h^{\prime}(e)=e^{1 / \gamma-1}>0$ calculating $\pi_{e} / H$, equation (10) implies (see Appendix B)

A central finding in the empirical labour market literature is that low skilled labour supply tends to be quite unresponsive along the intensive margin. See for empirical evidence, e.g. Immervoll et al. (2007) and Blundell and MaCurdy (1999). To provide a relative simple model, we adopt this strong assumption for high skilled labour supply. However, our main result does not change if we assume a more realistic assumption like complete elastic of high skilled labour supply. See also conclusion. 


$$
e=K\left(\tau w_{H}\right)^{\gamma} \text {, }
$$

where $K=\left[\rho m^{-(1-\rho)} a^{a \rho}(1-a)^{1-a \rho}\right]^{\gamma}$ and $\gamma=\frac{e_{\tau} \tau}{e}=\frac{e_{w_{H}} w_{H}}{e}$ is the elasticity of the representative skilled worker's effort with respect to profit sharing and the skilled wage. ${ }^{12}$ Therefore, the optimal effort by the representative skilled worker is influenced positively by the income parts, $e_{w_{H}}=\frac{\gamma e}{w_{H}}>0$ and $e_{\tau}=\frac{\gamma e}{\tau}>0$, so that both the base wage and profit sharing enhance the productivity by increasing effort provision and positively affect labour demand indirectly. ${ }^{13}$ But outsourcing will have no direct effect in case of perfect substitutability between outsourcing and domestic unskilled labour.

\section{III.2.2 Market Equilibrium for Skilled Wage Formation}

Unlike in the case of unskilled workers, we assume that the skilled wage $w_{H}$ is determined by the market equilibrium concerning the equality of the labour demand function and the labour supply function. In the case of our constant labour supply, $H^{s}=\mu$, the equality $H=H^{s}$ gives $\frac{m a}{1-a} w_{H}^{-(1+\varepsilon)} w_{L}^{-(\delta-1)} e^{\varepsilon}=\mu$, which allows to solve $w_{H}=\left[\frac{\mu(1-a)}{m a}\right]^{-\frac{1}{1+\varepsilon}} w_{L}^{-\left(\frac{\delta-1}{1+\varepsilon}\right)} e^{\frac{\varepsilon}{1+\varepsilon}}$, and by using $X=\left[\frac{\mu(1-a)}{m a}\right]^{-\frac{1}{1+\varepsilon}}$ and $e=K\left(\tau w_{H}\right)^{\gamma}$, we can rewrite it explicitly as follows

12 The case of zero effort elasticity describes a firm, where individual worker has no influence on the firm's profit. Thus she/he has no incentive to increase effort and will provide only a minimum effort level of one. By implementing profit sharing the firm distributes only a part of its profit to the worker without effects on effort or profit. So it is beneficial for the firm to avoid profit sharing. In this scenario the optimal profit share will be zero (see Koskela and König (2008a, b)). Since we are analyzing the effect of implementing profit sharing we assume positive effort elasticity.

13 This finding lies in conformity with empirics (see e.g. Booth and Frank (1999), Cable and Wilson (1990), Cahuc and Dormont (1997), Kruse (1992) and Wadhwani and Wall (1990)). Also in the theoretical focus of the literature we find evidence of increasing effort by higher wages, see e.g. Lin et al. (2002). 


$$
w_{H}=Z w_{L}^{-\left(\frac{\delta-1}{1+\varepsilon(1-\gamma)}\right)} \tau^{\frac{\varepsilon \gamma}{1+\varepsilon(1-\gamma)}}
$$

where $Z=X^{\frac{1+\varepsilon}{1+\varepsilon(1-\gamma)}} K^{\frac{\varepsilon}{1+\varepsilon(1-\gamma)}}>0$. Knowing this, we can look on comparative statics of $w_{H}$ in terms of $w_{L}$ :

$$
\frac{\partial w_{H}}{\partial w_{L}}=-\left(\frac{\delta-1}{1+\varepsilon(1-\gamma)}\right) Z w_{L}^{-\left(\frac{\delta-1}{1+\varepsilon}\right)-1} \tau^{\frac{\varepsilon \gamma}{1+\varepsilon(1-\gamma)}},
$$

so that

$$
\frac{\partial w_{H}}{\partial w_{L}}=-\frac{(\delta-1)}{1+\varepsilon(1-\gamma)} \frac{w_{H}}{w_{L}}<0 .
$$

Equation (13) lies in conformity with empirics concerning the negative relationship between skilled and unskilled wages in the presence of outsourcing. ${ }^{14}$

Differentiating (12) with respect to profit sharing $\tau$ gives the direct effect on the high skilled wage

$$
\frac{\partial w_{H}}{\partial \tau}=\frac{\varepsilon \gamma}{1+\varepsilon(1-\gamma)} \frac{w_{H}}{\tau}>0
$$

We can now summarize our findings regarding the properties of the skilled wage determination in the presence of outsourcing as follows.

Proposition 2: In the presence of flexible outsourcing

14 See evidence from various countries which lies in conformity with this, e.g. Braun and Scheffel (2007a), Feenstra and Hanson (1999), Haskel and Slaughter (2001), Hijzen et al. (2005), Hijzen (2007), Egger and Egger (2006), Munch and Skaksen (2005), Riley and Young (2007) and Geishecker and Görg (2008). 
(a) the skilled wage depends negatively on the unskilled wage and positively in a direct way on profit sharing, and

(b) the skilled wage is also directly independent of the cost of outsourcing, but depends on the unskilled wage, so that higher outsourcing cost affects indirectly, whereas

(c) the skilled effort depends positively both on the skilled wage and profit sharing.

These results are intuitively in our setting. Since high and low skilled labour are complements, a higher low skilled wage will reduce both labour demands. Thus, in the competitive wage formation for high skilled labour the lower labour demand for given labour supply will induce a smaller high skilled wage, ceteris paribus. The positive direct effect of profit sharing can be explained as follows. Higher profit sharing will increase the effort, which leads for given wage level to a higher productivity. This increases labour demand and results in a higher wage for given labour supply.

\section{Unskilled Wage Formation by Monopoly Labour Union under Committed Profit Sharing}

Now we analyze the wage formation of unskilled workers, which takes place in anticipation of optimal labour and outsourcing decisions by the firm. We analyze the wage formation by the monopoly labour union (see also Cahuc and Zylberberg (2004), p. 401-403 concerning the monopoly union specification), which determines the wage for unskilled workers in anticipation of optimal in-house unskilled labour demand in the presence of flexible outsourcing and of market equilibrium for the high-skilled wage $w_{H} \cdot 15$

15 In Western European countries, which we like to focus on, labour market institutions are close to this (see e.g. Freeman (2008)). 


\section{IV.1. Wage Formation by the Monopoly Labour Union under Committed Profit Sharing}

The objective function of the labour union of unskilled workers is assumed to be $V=\left(w_{L}-b_{L}\right) L+b_{L} N$, where $b_{L}$ is the (exogenous) outside option available for the unskilled workers and $N$ is the number of labour union members. The monopoly labour union sets wage for the unskilled workers so as to maximize the surplus according to

$$
\underbrace{\max }_{w_{L}} V=\left(w_{L}-b_{L}\right) L+b_{L} N
$$

s.t. $\quad L=m w_{L}^{-\delta} w_{H}^{-\varepsilon} e^{\varepsilon}-M=m w_{L}^{-\delta} w_{H}^{-\varepsilon} e^{\varepsilon}-\left(\frac{w_{L}}{c}\right)$ and $H=\frac{m a}{1-a} w_{H}^{-(1+\varepsilon)} w_{L}^{1-\delta} e^{\varepsilon}=H^{s}=\mu$, which implies $w_{H}=Z w_{L}^{-\left(\frac{\delta-1}{1+\varepsilon(1-\gamma)}\right)} \tau^{\frac{\varepsilon \gamma}{1+\varepsilon(1-\gamma)}}$ (see equation (12)).

The first-order condition associated with (15) is

$$
V_{w_{L}}=\frac{L}{w_{L}}\left[w_{L}+\left(w_{L}-b_{L}\right) \frac{w_{L}}{L} \frac{d L}{d w_{L}}\right]=0,
$$

with $\frac{d L}{d w_{L}}=\frac{\partial L}{\partial w_{L}}+\frac{\partial L}{\partial w_{H}} \cdot \frac{\partial w_{H}}{\partial w_{L}}$. Plug in the labour demand reaction in equation (16), we have $V_{w_{L}}=\frac{L}{w_{L}}\left[w_{L}+\left(w_{L}-b_{L}\right)\left(\frac{\partial L}{\partial w_{L}} \cdot \frac{w_{L}}{L}+\frac{\partial L}{\partial w_{H}} \cdot \frac{w_{H}}{L} \cdot \frac{w_{L}}{w_{H}} \cdot \frac{\partial w_{H}}{\partial w_{L}}\right)\right]=0$. Simplifying this expression leads to

$$
V_{w_{L}}=w_{L}\left[1-\left(\eta_{L}+\eta_{H} \frac{\partial w_{H}}{\partial w_{L}} \frac{w_{L}}{w_{H}}\right)\right]+b_{L}\left(\eta_{L}+\eta_{H} \frac{\partial w_{H}}{\partial w_{L}} \frac{w_{L}}{w_{H}}\right)=0
$$


where $\frac{\partial w_{H}}{\partial w_{L}} \frac{w_{L}}{w_{H}}=-\frac{(\delta-1)}{1+\varepsilon(1-\gamma)}$, the own wage elasticity of unskilled labour demand is $\eta_{L}=\delta+(1+\delta) \frac{W_{L}}{c L}$ and the cross wage elasticity of unskilled labour demand $\eta_{H}=\varepsilon\left(1+\frac{w_{L}}{c L}\right)=\eta_{e}$. These unskilled labour demand elasticities are not constant because the unskilled labour demand, $L=m w_{L}^{-\delta} w_{H}^{-\varepsilon} e^{\varepsilon}-\left(\frac{w_{L}}{c}\right)$, depends negatively on the skilled wage and the unskilled wage but positively on the skilled worker's effort and the cost of outsourcing.

Simplifying the first order condition, we get (see Appendix C)

$$
w_{L}\left(c, w_{H}, b_{L}, e, \tau\right)=\left(\frac{\bar{\eta}_{L}}{\bar{\eta}_{L}-1}\right) b_{L}=\frac{\beta L+(1+\beta) M}{(\beta-1) L+(1+\beta) M} b_{L},
$$

so that the total wage elasticity, also allowing for the relationship between skilled and unskilled $\quad$ wages, $\quad \bar{\eta}_{L}=\beta\left(1+\frac{M}{L}\right)+\frac{M}{L}>1, \quad$ where $\delta-\frac{\varepsilon(\delta-1)}{1+\varepsilon(1-\gamma)}=\frac{1}{1-\rho}\left[\frac{1-\rho-(1-\rho a) \rho a \gamma}{1-\rho+\rho a(1-\gamma)}\right]=\beta, \quad$ outsourcing $\quad M=\frac{w_{L}}{c} \quad$ and domestic unskilled labour demand $L=m w_{L}^{-\delta} w_{H}^{-\varepsilon} e^{\varepsilon}-\left(\frac{w_{L}}{c}\right)$. It is important to emphasize that the optimal unskilled wage (18), even in the case of the monopoly labour union, is an implicit form in the presence of outsourcing, because the mark-up $A=\frac{\beta L+(1+\beta) M}{(\beta-1) L+(1+\beta) M}>1$ depends on the unskilled wage rate in a non-linear way so that it cannot be solved explicitly for the optimal domestic unskilled wage. In the absence of outsourcing the mark-up is constant, i.e. $\left.A\right|_{M=0}=\frac{\beta}{(\beta-1)}$.

In order to answer our research question and characterize the effect of outsourcing cost on the unskilled wage formation, we therefore apply the implicit 
differentiation. Differentiating the wage formation (18) with respect to the unskilled wage and the outsourcing cost gives

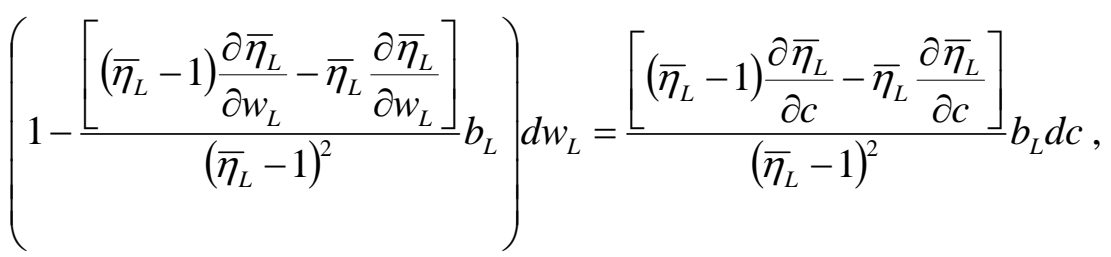

which can be expressed as $\frac{d w_{L}}{d c}=-\frac{\frac{\partial \bar{\eta}_{L}}{\partial c}}{\left(\bar{\eta}_{L}-1\right)^{2}} b_{L} /\left(1+\frac{\frac{\partial \bar{\eta}_{L}}{\partial w_{L}}}{\left(\bar{\eta}_{L}-1\right)^{2}} b_{L}\right)$. Using $b_{L}=\frac{w_{L}\left(\bar{\eta}_{L}-1\right)}{\bar{\eta}_{L}}$, and calculating

$$
\frac{\partial \bar{\eta}_{L}}{\partial c}=(1+\beta)\left[\frac{\left(L M_{c}-M L_{c}\right)}{L^{2}}\right]=-(1+\beta) \frac{M}{c L}\left(1+\frac{M}{L}\right)<0
$$

and

$$
\frac{\partial \bar{\eta}_{L}}{\partial w_{L}}=\frac{(1+\beta) M}{w_{L} L}\left[1+\frac{M}{L}+\left(\frac{\delta+\varepsilon(1-\gamma)}{1+\varepsilon(1-\gamma)}\right)\left(1+\frac{M}{L}\right)\right]>0
$$

(see Appendix D) the relationship between the unskilled wage formation and outsourcing cost can be written as follows

$$
\frac{d w_{L}}{d c}=-\frac{\frac{\partial \bar{\eta}_{L}}{\partial c} \frac{w_{L}}{\bar{\eta}_{L}}}{\bar{\eta}_{L}-1+\frac{\partial \bar{\eta}_{L}}{\partial w_{L}} \frac{w_{L}}{\bar{\eta}_{L}}}>0
$$

so that lower (higher) outsourcing cost will decrease (increase) the wage of unskilled domestic workers. 
Differentiating the implicit wage formation (18) with respect to the profit sharing and the unskilled wage gives

$$
\left(1-\frac{\left[\left(\bar{\eta}_{L}-1\right) \frac{\partial \bar{\eta}_{L}}{\partial w_{L}}-\bar{\eta}_{L} \frac{\partial \bar{\eta}_{L}}{\partial w_{L}}\right]}{\left(\bar{\eta}_{L}-1\right)^{2}} b_{L}\right) d w_{L}=\frac{\left[\left(\bar{\eta}_{L}-1\right) \frac{\partial \bar{\eta}_{L}}{\partial \tau}-\bar{\eta}_{L} \frac{\partial \bar{\eta}_{L}}{\partial \tau}\right]}{\left(\bar{\eta}_{L}-1\right)^{2}} b_{L} d \tau
$$

This can be simplified by using $\frac{\partial \bar{\eta}_{L}}{\partial \tau}=-(1+\beta) \frac{M}{L}\left(1+\frac{M}{L}\right)\left[\frac{\varepsilon}{e} \frac{d e}{d \tau}-\frac{\varepsilon}{w_{H}} \frac{\partial w_{H}}{\partial \tau}\right]$ with $\frac{d e}{d \tau}=\frac{\partial e}{\partial \tau}+\frac{\partial e}{\partial w_{H}} \frac{\partial w_{H}}{\partial \tau}, \quad$ which yields the negative expression $\frac{\partial \bar{\eta}_{L}}{\partial \tau}=-\frac{M}{L}\left(1+\frac{M}{L}\right) \frac{\varepsilon \gamma \cdot(1+\beta)}{[1+\varepsilon(1-\gamma)] \cdot \tau}<0$. Therefore we have

$$
\frac{d w_{L}}{d \tau}=-\frac{\frac{\partial \bar{\eta}_{L}}{\partial \tau} \frac{w_{L}}{\bar{\eta}_{L}}}{\bar{\eta}_{L}-1+\frac{\partial \bar{\eta}_{L}}{\partial w_{L}} \frac{w_{L}}{\bar{\eta}_{L}}}>0
$$

so that profit sharing for skilled workers will have a positive effect on the domestic unskilled wage.

Knowing this, we are able to find an answer to our main question: How does the implementation of profit sharing for high skilled workers influence outsourcing activities? Differentiating (4) in terms of profit sharing gives

$$
\frac{d M}{d \tau}=\frac{1}{c} \frac{d w_{L}}{d \tau}>0
$$

so that the effect of outsourcing activities is driven by the effect on low skilled wage, which is positive. 
We can now summarize our findings with answering: How does the implementation of profit sharing for skilled workers in the presence of outsourcing affect the low skilled workers’ wage and outsourcing?

Proposition 3: In the presence of flexible outsourcing

(a) higher profit sharing for the skilled worker has a positive effect on the wage for the unskilled labor and

(b) higher profit sharing for the skilled worker has an enhancing effect on outsourcing, whereas

(c) lower cost of outsourcing decreases the wage for the unskilled labour.

Higher profit sharing increases the skilled labour demand and since the labour inputs have assumed to be complements, also the low skilled labour demand raises. Thus, a higher low skilled wage will have a smaller loss for the trade union via less dismissal and the union can set a higher wage. Since higher profit sharing increases the firm's profit, the trade union gets a higher share of this due to higher low skilled wages. But the wage enhancing effect will also induce a higher outsourcing demand, which can be explained by the substitutability of domestic low skilled labour services and foreign intermediate goods, which also determines the positive correlation of domestic low skilled wage and outsourcing cost. Lower outsourcing cost means for given wage level a higher outsourcing demand and more elastic domestic wage elasticity (see equation (19a), which lies in conformity with empirics). Thus the opportunity for the trade union to set higher wages falls. To avoid outsourcing and make integrated production more attractive, the trade union reacts with a decreasing low skilled wage.

However, up to now we have only analyzed the direct effect of profit sharing and outsourcing cost on the wage for high skilled worker. Using the above results, we can show the overall effects of outsourcing cost and implementing profit sharing for the high skilled wage. Using equations (20), and (21) jointly with equations (13) and (14), 
these overall effects can be expressed as $\frac{d w_{H}}{d \tau}=\underbrace{\frac{\partial w_{H}}{\partial \tau}}_{+}+\underbrace{\frac{\partial w_{H}}{\partial w_{L}} \frac{d w_{L}}{d \tau}}_{-}=$? and $\frac{d w_{H}}{d c}=\underbrace{\frac{\partial w_{H}}{\partial w_{L}}}_{-} \cdot \underbrace{\frac{d w_{L}}{d c}}_{+}<0$.

Following from this, lower cost of outsourcing will raise the domestic skilled wage and decrease the unskilled wage and thus lead to higher wage gap.

In line with earlier research on homogenous labour force and empirical studies, we also find an ambiguous effect of profit sharing on the domestic skilled wage, so that profit sharing could have a supplementary or complementary character for the base wage. $^{16}$

We can summarize our findings in

Proposition 4: In the presence of flexible outsourcing

(a) lower cost of outsourcing, by decreasing the wage for the unskilled labour and increasing the wage for the skilled labour, induces higher wage dispersion, whereas

(b) higher profit sharing for the skilled worker can have a supplementary or compensatory character for the skilled labour.

Due to the substitutability of international outsourcing and domestic low skilled labour services, lower outsourcing cost increases labour demand elasticity and decreases the domestic low skilled wage so that the low skilled labour demand rises. Since low skilled and high skilled labour are complements, also the high skilled labour demand increases so that for given high skilled labour supply, the high skilled wage increases, thereby inducing higher wage dispersion, which lies in conformity with empirics.

16 For theoretical analysis in the case of homogeneous labour see Koskela and König (2008b). There is also some empirical evidence for both properties. Black and Lynch (2004) show by using U.S. data, that profit sharing results in lower regular pay for workers, which implies a compensatory character, but in Wadhwani and Wall (1990) by using UK data and also in Kraft and Ugarkovic (2005) by using German panel data, it has been shown that introducing profit sharing does not reduce the wage, which implies a supplementary character. See also the book by Ugarkovic (2008). 
As we showed, implementing profit sharing affects high skilled wage positively in a direct way. But there is also an indirect channel due to the complementary relationship of labour inputs. Since higher profit sharing induces higher low skilled wage, this will reduce the labour demand for both types. This leads by assuming a competitively wage formation for high skilled worker to a lower skilled wage. Thus, there are two opposed effects: the wage increasing direct effect, which describes the higher skilled labour demand due to higher effort and profit, and the wage decreasing indirect effect, which is described by the lower skilled labour demand due to a higher low skilled wage. ${ }^{17}$

\section{Conclusion}

In this paper, we have tried to describe a more realistic framework of flexible outsourcing in a partly unionized dual labour market by using reasonable assumptions. In western European countries we often observe that unlike low skilled workers, which are organized in trade union, high skilled wages are mostly determined competitively. However, high skilled workers could, unlike the low skilled labour force, directly participate in the firm's success via profit sharing. But this will affect the wage determination of both types of labour and affect the outsourcing demand. Thereby, we answer the following questions: First, how does the implementation of profit sharing for high skilled workers influence outsourcing activities? Second, how does the opportunity of flexible outsourcing and its cost influence the wage for both types of workers and profit sharing? And third, what is the relationship between profit sharing and wage levels?

In the above analyses we could show that the wage of the high skilled workers will be negatively affected by the wage of the low skilled. The overall effect of implementing committed profit sharing on high skilled wage is ambiguous, since on

17 For giving a policy statement as a support for the aim of securing existent jobs, we can also sum up the following: Without profit sharing to high skilled there is no wage increasing effect for unionized low skills, what avoid outsourcing. Job security plus decreasing wage dispersion can occur, if the policy can also increase the cost of outsourcing. 
one side there is a wage increasing direct effect, such that profit sharing has a supplementary character, but on the other side there is a negative indirect effect via the wage for the low skilled worker. We also show that lower outsourcing cost leads to falling wages for the low skilled. However, the high skilled wage does not directly depend on outsourcing cost. Also, here there is only an indirect effect via low skilled wage working. Our analysis shows that lower outsourcing cost will at the same time decrease the low skilled wage and increase the high skilled wage and thus raise the wage dispersion. Also, we could conclude that the effect of profit sharing on outsourcing activities is indirect via the effect on low skilled wage and ambiguous. This follows since outsourcing demand is only affected by the relation of low skilled worker wage and outsourcing cost, where profit sharing affects the low skilled wage.

Of course, in our analysis we have the assumption of a constant labour supply of high skills. If we relax this assumption by using the concept of perfect mobile high skills we get an elastic high skilled labour supply, but anymore, high skilled labour demand would be positively affected by effort. Therefore, implementing profit sharing scheme increase high skilled employment and due to the complementary relationship of labour types, this would raise the opportunity for the labour union to realize a higher low skill wage and increase outsourcing. So the qualitative result is the same.

As analyzed in the literature, also a flexible profit sharing system could be implemented. Since here the profit share and the wage for high skilled worker would be decided after the wage negotiation for the low skilled, there is no effect of implementing such a system on low skilled wage and thus on outsourcing demand. However, similar to the argumentation of Koskela and König (2008b), it can be shown that in the presence of outsourcing such a profit sharing system provides a lower profit share than in the absence of outsourcing.

\section{References:}

Amiti, M. and S.-J. Wei (2005): Fear of Service Outsourcing: Is It Justified?, Economic Policy, 20, 307-347. 
Black, S.E. and L.-M. Lynch (2004): What's Driving the New Economy: The Benefits of Workplace Innovation, Economic Journal, 114, F97-F116.

Blundell, R.W. and T. MaCurdy (1999): Labour Supply: A Review of Alternative Approaches, in O. Ashenfelter and D. Card (eds): Handbook of Labor Economics, vol. 3A, 1559-1604.

Booth, A.J. and J. Frank (1999): Earnings, Productivity, and Performed-Related Pay, Journal of Labor Economics, 17(3), 447-463.

Braun, F.D. and J. Scheffel (2007a): Does International Outsourcing Depress Union Wages?, SFB 649 Discussion Paper, 2007-033, Humbold Universität zu Berlin.

Braun, F.D. and J. Scheffel (2007b): A Note on the Effect of Outsourcing on Union Wages, SFB 649 Discussion Paper, 2007-034, Humbold Universität zu Berlin.

Cable, J. and N. Wilson (1990): Profit Sharing and Productivity: Some Further Evidence, Economic Journal, 100, 550-555.

Cahuc, P. and B. Dormont (1997): Profit Sharing: Does It Increase Productivity and Employment? A Theoretical Model and Empirical Evidence on French Micro Data, Labour Economics, 4, 293-319.

Cahuc, P. and A. Zylberberg (2004): Labor Economics, MIT Pess.

Conyon, M. and R. Freeman (2001): Shared Modes of Compensation and Firm Performance: UK Evidence, NBER Working Paper No. 8448.

Danthine, J.-P. and J. Hunt (1994): Wage Bargaining Structure, Employment and Economic Integration, Economic Journal, 104, 528-541.

Davidson, C., S.J. Matuz, and D.R. Nelson (2007): Can Compensation Save Free Trade?, Journal of International Economics, 71, 167-186.

Davidson, C., S.J. Matuz, and A. Shevchenko (2008): Globalization and Firm Level Adjustment with Imperfect Labour Markets, Journal of International Economics, 75, 295-309.

Egger, H. and P. Egger (2006): International Outsourcing and the Productivity of LowSkilled Labor in the EU, Economic Inquiry, 44, 98-108.

Ethier, W.J. (2005): Globalization, Globalisation: Trade, Technology, and Wages, International Review of Economics and Finance, 14, 237-258.

Feenstra, R.C. and G.H. Hanson (1999): The Impact of Outsourcing and HighTechnology Capital on Wages: Estimates for the United States, 1979-1990, Quarterly Journal of Economics, 114, 907-940.

Freeman, R.B. and R. Schettkat (2001): Marketization of Production and the USEurope Employment Gap, Oxford Bulleting of Economics and Statistics, 63, 647670.

Freeman, R.B. (2008): Labor Market Institutions Around the World, CEP Discussion Paper No 08-844, January, Washington D.C.

Geischecker, I. and H. Görg (2008): Winners and Losers: A Micro-Level Analysis of International Outsourcing and Wages, Canadian Journal of Economics, 41, 243270.

Hasan, R., D. Mitra and R.W. Ramaswamy (2007): Trade Reforms, Labor Regulations, and Labor-Demand Elasticities: Empirical Evidence from India, Review of Economics and Statistics, 89(3), 466-481.

Haskel, J. abd M.J. Slaughter (2001): Trade, Technology and U.K. Wage Inequality, Economic Journal, 111, 163-187. 
Hijzen, A. (2007): International Outsourcing, Technological Change, and Wage Inequality, Review of International Economics, 15, 188-205.

Hijzen, A., H. Görg and R.C. Hine (2005): International Outsourcing and the Skill Structure of Labour Demand in the United Kingdom, Economic Journal, 115, 860-878.

Immervoll, H., H.J. Kleven, C.T. Kreiner and E. Saez (2007): Welfare Reform in European Countries: A Microsimulation Analysis, Economic Journal, 117, 1-44.

Koskela, E. (2008): The Effects of Labour Tax Progression under Nash-Bargaining and Flexible Outsourcing, IZA Discussion Paper No. 3501.

Koskela, E. and J. König (2008a): Strategic Outsourcing, Profit Sharing and Equilibrium Unemployment, IZA Discussion Paper No. 3413, March.

Koskela, E. and J. König (2008b): Flexible Outsourcing, Profit Sharing and Equilibrium Unemployment, CESifo Working Paper No. 2382, August.

Koskela, E. and P. Poutvaara (2008a): Outsourcing and Labor Taxation in Dual Labor Market, CESifo Working Paper No. 2333, June.

Koskela, E. and P. Poutvaara (2008b): Flexible Outsourcing and the Impacts of Labour Taxation in European Welfare States, CESifo Working Paper No. 2449, October.

Koskela, E. and R. Schöb (2008): Outsourcing of Unionized Firms and the Impact of Labour Market Policy Reforms, CESifo Working Paper No. 2360, July.

Koskela, E. and R. Stenbacka (2006): Flexible and Committed Profit Sharing with Wage Bargaining: Implications for Equilibrium Unemployment, Journal of Economics, 87(2), 159-180.

Koskela, E. and R. Stenbacka (2007): Equilibrium Unemployment with Outsourcing and Wage Solidarity under Labour Market Imperfections, CESifo Working Paper No. 1988, revised in December 2008 to European Economic Review.

Kraft, K. and M. Ugarkovic (2005): Profit-Sharing: Supplement or Substitute?, Dortmund University, Germany.

Kruse, D.L. (1992): Profit Sharing and Productivity: Microeconomic Evidence from the United States, Economic Journal, 102, 24-36.

Lin, C.C., J.-J. Chang and C.-C. Lai (2002): Profit Sharing as a Worker Discipline Device, Economic Modelling, 19(5), 815-828.

Lommerud, K.E., O.R. Straume and L. Sorgard (2006): National versus International Mergers in Unionized Oligopoly, Rand Journal of Economics, 37, 212-233.

Lommerud, K.E., F. Meland, O.R. Straume (2009): Can Deunionization Lead to International Outsourcing, Journal of International Economics, 77, 109-119.

Munch, J.R. and J.R. Skaksen (2005): Specialization, Outsourcing and Wages, IZA Discussion Paper No. 1907, December, University of Bonn, forthcoming in: Review of World Economics.

Pendleton, A., E. Poutsma, J. van Ommeren and C. Brester (2001): Employee Share Ownership and Profit Sharing in the European Union, Office for Official Publications of the European Commission, Luxembourg.

Perry, C.R. (1997): Outsourcing and Union Power, Journal of Labor Research, 18, 521-534.

Riley, R. and G. Young (2007): Skill Heterogeneity and Equilibrium Unemployment, Oxford Economic Papers, 59, 702-725. 
Rishi, M. and S. C. Saxena (2004): Is Outsourcing Really as Bad as It Is Made Sound?

A Re-assessment and Some Perspective, Working Paper, University of Pittsburgh.

Saint-Paul, G. (1996): Dual Labor Markets: A Macroeconomic Perspective, MIT Press.

Senses, M.Z. (2006): The Effects of Outsourcing on the Elasticity of Labor Demand, CES Discussion Paper, Washington D.C., March.

Slaughter, M. (2001): International Trade and Labor-Demand Elasticities, Journal of International Economics, 54, 27-56.

Skaksen, J.R. (2004): International Outsourcing When Labour Markets Are Unionized, Canadian Journal of Economics, 37 (1), 78-94.

Skaksen, J.R. and J.R. Sorensen (2001): Should Trade Unions Appreciate Foreign Direct Investment?, Journal of International Economics, 55(2), 379-390.

Ugarkovic M. (2008): Profit-Sharing and Company Performance, Deutscher Universitäts-Verlag.

Wadhwani, S. and M. Wall (1990): The Effects of Profit Sharing on Employment, Wages, Stock Returns and Productivity: Evidence from U.K. Micro Data, Economic Journal, 100, 1-17.

Zhao, L. (1998): The Impact of Foreign Direct Investment on Wages and Employment, Oxford Economic Papers, 50, 284-301.

Zhao, L. (2001): Unionization, Vertical Markets, and the Outsourcing of Multinationals, Journal of International Economics, 55(1), 187-202.

\section{Appendix A: Optimal Unskilled Labour Demand}

Substituting the RHS of (3) for $H$ into (2b) gives

$\rho\left[e^{a}\left(\frac{w_{L}}{w_{H}}\right)^{a}\left(\frac{a}{1-a}\right)^{a}(L+M)^{a}(L+M)^{1-a}\right]^{\rho-1}(1-a) e^{a}\left(\frac{w_{L}}{w_{H}}\right)^{a}\left(\frac{a}{1-a}\right)^{a}(L+M)^{a}(L+M)^{-a}=w_{L}$

so that $\rho\left[e^{a}\left(\frac{w_{L}}{w_{H}}\right)^{a}\left(\frac{a}{1-a}\right)^{a}(L+M)\right]^{\rho-1}(1-a) e^{a}\left(\frac{w_{L}}{w_{H}}\right)^{a}\left(\frac{a}{1-a}\right)^{a}=w_{L}$

which is equivalent to

$(L+M)^{\rho-1}\left(\frac{w_{L}}{w_{H}}\right)^{a \rho}(1-a)\left(\frac{a}{1-a}\right)^{a \rho} e^{a \rho}=\rho^{-1} w_{L}$.

Simplifying (A3) with $m=\left[\rho a^{a \rho}(1-a)^{1-a \rho}\right]^{\frac{1}{1-\rho}}>0, \delta=\frac{1-\rho a}{1-\rho}>1$ and $\varepsilon=\frac{\rho a}{1-\rho}>0$, give (5). QED.

\section{Appendix B: Optimal Skilled Employee Effort}


The first-order condition in terms of effort determination from (9) is $U_{e}=\frac{\tau}{H} \pi_{e}-h^{\prime}(e)=0$, where $h^{\prime}(e)=e^{(1 / \gamma)-1}$ and

$\tau \frac{\pi_{e}}{H}=\tau \rho a\left[(e H)^{a}(L+M)^{1-a}\right]^{\rho-1}(e H)^{a-1}(L+M)^{1-a}=\tau \rho a(e H)^{a \rho-1}(L+M)^{(1-a) \rho}$

Using equation (8) $H=\frac{m a}{1-a} w_{H}^{-(1+\varepsilon)} w_{L}^{-(\delta-1)} e^{\varepsilon}$ and equation (5) $L+M=m w_{L}^{-\delta} w_{H}^{-\varepsilon} e^{\varepsilon}$ the first-order condition $U_{e}=\frac{\tau}{H} \pi_{e}-g^{\prime}(e)=0$ can be written after calculations as follows $\left[\rho m^{-(1-\rho)} a^{1+a \rho}(1-a)^{1-a \rho}\right] \tau^{\gamma} w_{H}^{\gamma[-\varepsilon(1-a) \rho-(1+\varepsilon)(a \rho-1)]} w_{L}^{\gamma[-(\delta-1)(a \rho-1) \rho-\delta(1-a) \rho]}=$ $e^{1-\gamma-\gamma[(1+\varepsilon)(a \rho-1)+\varepsilon(1-a) \rho]}$

where $-\varepsilon(1-a) \rho-(1+\varepsilon)(a \rho-1)=1,-(\delta-1)(a \rho-1)-\delta(1-a) \rho=0$ and $1-\gamma-\delta[(1+\varepsilon)(a \rho-1)+\varepsilon(1-a) \rho]=-1$. By substituting these into (B2) gives equation (11). QED.

\section{Appendix C: Optimal Unskilled Wage Setting}

The first-order condition associated with $\underbrace{\max }_{w_{L}} V=\left(w_{L}-b_{L}\right) L$ s.t. $\pi_{L}=0$ and $H=\mu$ can be written as follows

$$
V_{w_{L}}=w_{L}\left[1-\left(\eta_{L}+\eta_{H} \frac{\partial w_{H}}{\partial w_{L}} \frac{w_{L}}{w_{H}}\right)\right]+b_{L}\left(\eta_{L}+\eta_{H} \frac{\partial w_{H}}{\partial w_{L}} \frac{w_{L}}{w_{H}}\right)=0
$$

where the own wage elasticity of labour demand is $\eta_{L}=\delta\left(1+\frac{M}{L}\right)+\frac{M}{L}=\delta+(1+\delta) \frac{M}{L}$, the cross wage elasticity is $\eta_{H}=\varepsilon\left(1+\gamma \frac{M}{L}\right)=\eta_{e}$ and the labour demand is $L=m w_{L}^{-\delta} w_{H}^{-\varepsilon} e^{\varepsilon}-M^{*}=m w_{L}^{-\delta} w_{H}^{-\varepsilon} e^{\varepsilon}-\left(\frac{w_{L}}{c}\right)$. The market equilibrium for the skilled labour is

$$
w_{H}=\left[\frac{\mu(1-a)}{m a}\right]^{-\frac{1}{1+\varepsilon}} w_{L}^{-\left(\frac{\delta-1}{1+\varepsilon}\right)} e^{\frac{\varepsilon}{1+\varepsilon}}
$$

which can be expressed as equation (12) so that 
$\frac{\partial w_{H}}{\partial w_{L}}=-\frac{(\delta-1)}{1+\varepsilon(1-\gamma)} \frac{w_{H}}{w_{L}}<0$

Using (C3) gives $\frac{\partial w_{H}}{\partial w_{L}} \frac{w_{L}}{w_{H}}=-\frac{(\delta-1)}{1+\varepsilon(1-\gamma)}<0$, which all together implies equation (18) because $\delta-\frac{\varepsilon(\delta-1)}{1+\varepsilon(1-\gamma)}=\frac{\delta+\varepsilon-\delta \varepsilon \gamma}{1+\varepsilon(1-\gamma)}=\frac{1}{1-\rho}\left[\frac{1-\rho-(1-\rho a) \rho a \gamma}{1-\rho+\rho a(1-\gamma)}\right]=\beta$.QED.

\section{Appendix D: Effects on Low Skilled Wage}

Differentiating $\quad \bar{\eta}_{L}=\beta\left(1+\frac{M}{L}\right)+\frac{M}{L}>0 \quad$ with respect $\quad$ to $w_{L}$ gives $\frac{\partial \bar{\eta}_{L}}{\partial w_{L}}=(1+\beta)\left(\frac{L \frac{d M}{d w_{L}}-M \frac{d L}{d w_{L}}}{L^{2}}\right)=(1+\beta) \frac{M}{w_{L} L}\left(\frac{d M}{d w_{L}} \frac{w_{L}}{M}-\frac{d L}{d w_{L}} \frac{w_{L}}{L}\right)$

where $\quad \frac{d M}{d w_{L}} \frac{w_{L}}{M}=1 \quad$ from (4) and $\frac{d L}{d w_{L}}=\frac{\partial L}{\partial w_{L}}+\frac{\partial L}{\partial w_{H}} \cdot \frac{\partial w_{H}}{\partial w_{L}}$, where $\frac{\partial L}{\partial w_{L}}=-\delta m w_{L}^{-\delta-1} w_{H}^{-\varepsilon} e^{\varepsilon}-1 / c, \frac{\partial L}{\partial w_{H}}=-\varepsilon m w_{L}^{-\delta} w_{H}^{-\varepsilon-1} e^{\varepsilon}+\varepsilon m w_{L}^{-\delta} w_{H}^{-\varepsilon} e^{\varepsilon-1} e_{w_{H}}$ and from (13) $\frac{\partial w_{H}}{\partial w_{L}}=-\frac{(\delta-1)}{1+\varepsilon(1-\gamma)} \frac{w_{H}}{w_{L}}<0$. By using these $\frac{d L}{d w_{L}} \frac{w_{L}}{L}=\left(\frac{\partial L}{\partial w_{L}}+\frac{\partial L}{\partial w_{H}} \cdot \frac{\partial w_{H}}{\partial w_{L}}\right) \frac{w_{L}}{L}$ can be expressed as follows

$$
\frac{d L}{d w_{L}} \frac{w_{L}}{L}=\frac{w_{L}}{L}\left[-\frac{\delta}{w_{L}}(L+M)-\frac{M}{w_{L}}+\left[-\frac{\varepsilon}{w_{H}}(L+M)+\frac{\varepsilon \gamma}{w_{H}}(L+M)\right] \frac{\partial w_{H}}{\partial w_{L}}\right] .
$$

This expression can be simplified to $\frac{d L}{d w_{L}} \frac{w_{L}}{L}=-\frac{(L+M)}{L}\left[\frac{\varepsilon(1-\gamma)+\delta}{1+\varepsilon(1-\gamma)}\right]-\frac{M}{L}$ so that $\frac{d L}{d w_{L}} \frac{w_{L}}{L}<0$. Therefore, we have

$(1+\beta) \frac{M}{w_{L} L}\left(\frac{d M}{d w_{L}} \frac{w_{L}}{M}-\frac{d L}{d w_{L}} \frac{w_{L}}{L}\right)=(1+\beta) \frac{M}{w_{L} L}\left[1+\frac{M}{L}+\left(\frac{\varepsilon(1-\gamma)+\delta}{1+\varepsilon(1-\gamma)}\right)\left(1+\frac{M}{L}\right)\right]>0$ (D3)

QED. 


\section{CESifo Working Paper Series}

for full list see www.cesifo-group.org/wp

(address: Poschingerstr. 5, 81679 Munich, Germany, office@cesifo.de)

2469 Anna Montén and Marcel Thum, Ageing Municipalities, Gerontocracy and Fiscal Competition, November 2008

2470 Volker Meier and Matthias Wrede, Reducing the Excess Burden of Subsidizing the Stork: Joint Taxation, Individual Taxation, and Family Splitting, November 2008

2471 Gunther Schnabl and Christina Ziegler, Exchange Rate Regime and Wage Determination in Central and Eastern Europe, November 2008

2472 Kjell Erik Lommerud and Odd Rune Straume, Employment Protection versus Flexicurity: On Technology Adoption in Unionised Firms, November 2008

2473 Lukas Menkhoff, High-Frequency Analysis of Foreign Exchange Interventions: What do we learn?, November 2008

2474 Steven Poelhekke and Frederick van der Ploeg, Growth, Foreign Direct Investment and Urban Concentrations: Unbundling Spatial Lags, November 2008

2475 Helge Berger and Volker Nitsch, Gotcha! A Profile of Smuggling in International Trade, November 2008

2476 Robert Dur and Joeri Sol, Social Interaction, Co-Worker Altruism, and Incentives, November 2008

2477 Gaëtan Nicodème, Corporate Income Tax and Economic Distortions, November 2008

2478 Martin Jacob, Rainer Niemann and Martin Weiss, The Rich Demystified - A Reply to Bach, Corneo, and Steiner (2008), November 2008

2479 Scott Alan Carson, Demographic, Residential, and Socioeconomic Effects on the Distribution of $19^{\text {th }}$ Century African-American Stature, November 2008

2480 Burkhard Heer and Andreas Irmen, Population, Pensions, and Endogenous Economic Growth, November 2008

2481 Thomas Aronsson and Erkki Koskela, Optimal Redistributive Taxation and Provision of Public Input Goods in an Economy with Outsourcing and Unemployment, December 2008

2482 Stanley L. Winer, George Tridimas and Walter Hettich, Social Welfare and Coercion in Public Finance, December 2008

2483 Bruno S. Frey and Benno Torgler, Politicians: Be Killed or Survive, December 2008 
2484 Thiess Buettner, Nadine Riedel and Marco Runkel, Strategic Consolidation under Formula Apportionment, December 2008

2485 Irani Arraiz, David M. Drukker, Harry H. Kelejian and Ingmar R. Prucha, A Spatial Cliff-Ord-type Model with Heteroskedastic Innovations: Small and Large Sample Results, December 2008

2486 Oliver Falck, Michael Fritsch and Stephan Heblich, The Apple doesn't Fall far from the Tree: Location of Start-Ups Relative to Incumbents, December 2008

2487 Cary Deck and Harris Schlesinger, Exploring Higher-Order Risk Effects, December 2008

2488 Michael Kaganovich and Volker Meier, Social Security Systems, Human Capital, and Growth in a Small Open Economy, December 2008

2489 Mikael Elinder, Henrik Jordahl and Panu Poutvaara, Selfish and Prospective: Theory and Evidence of Pocketbook Voting, December 2008

2490 Maarten Bosker and Harry Garretsen, Economic Geography and Economic Development in Sub-Saharan Africa, December 2008

2491 Urs Fischbacher and Simon Gächter, Social Preferences, Beliefs, and the Dynamics of Free Riding in Public Good Experiments, December 2008

2492 Michael Hoel, Bush Meets Hotelling: Effects of Improved Renewable Energy Technology on Greenhouse Gas Emissions, December 2008

2493 Christian Bruns and Oliver Himmler, It's the Media, Stupid - How Media Activity Shapes Public Spending, December 2008

2494 Andreas Knabe and Ronnie Schöb, Minimum Wages and their Alternatives: A Critical Assessment, December 2008

2495 Sascha O. Becker, Peter H. Egger, Maximilian von Ehrlich and Robert Fenge, Going NUTS: The Effect of EU Structural Funds on Regional Performance, December 2008

2496 Robert Dur, Gift Exchange in the Workplace: Money or Attention?, December 2008

2497 Scott Alan Carson, Nineteenth Century Black and White US Statures: The Primary Sources of Vitamin D and their Relationship with Height, December 2008

2498 Thomas Crossley and Mario Jametti, Pension Benefit Insurance and Pension Plan Portfolio Choice, December 2008

2499 Sebastian Hauptmeier, Ferdinand Mittermaier and Johannes Rincke, Fiscal Competition over Taxes and Public Inputs: Theory and Evidence, December 2008

2500 Dirk Niepelt, Debt Maturity without Commitment, December 2008 
2501 Andrew Clark, Andreas Knabe and Steffen Rätzel, Boon or Bane? Others' Unemployment, Well-being and Job Insecurity, December 2008

2502 Lukas Menkhoff, Rafael R. Rebitzky and Michael Schröder, Heterogeneity in Exchange Rate Expectations: Evidence on the Chartist-Fundamentalist Approach, December 2008

2503 Salvador Barrios, Harry Huizinga, Luc Laeven and Gaëtan Nicodème, International Taxation and Multinational Firm Location Decisions, December 2008

2504 Andreas Irmen, Cross-Country Income Differences and Technology Diffusion in a Competitive World, December 2008

2505 Wenan Fei, Claude Fluet and Harris Schlesinger, Uncertain Bequest Needs and LongTerm Insurance Contracts, December 2008

2506 Wido Geis, Silke Uebelmesser and Martin Werding, How do Migrants Choose their Destination Country? An Analysis of Institutional Determinants, December 2008

2507 Hiroyuki Kasahara and Katsumi Shimotsu, Sequential Estimation of Structural Models with a Fixed Point Constraint, December 2008

2508 Barbara Hofmann, Work Incentives? Ex Post Effects of Unemployment Insurance Sanctions - Evidence from West Germany, December 2008

2509 Louis Hotte and Stanley L. Winer, The Demands for Environmental Regulation and for Trade in the Presence of Private Mitigation, December 2008

2510 Konstantinos Angelopoulos, Jim Malley and Apostolis Philippopoulos, Welfare Implications of Public Education Spending Rules, December 2008

2511 Robert Orlowski and Regina T. Riphahn, The East German Wage Structure after Transition, December 2008

2512 Michel Beine, Frédéric Docquier and Maurice Schiff, International Migration, Transfers of Norms and Home Country Fertility, December 2008

2513 Dirk Schindler and Benjamin Weigert, Educational and Wage Risk: Social Insurance vs. Quality of Education, December 2008

2514 Bernd Hayo and Stefan Voigt, The Relevance of Judicial Procedure for Economic Growth, December 2008

2515 Bruno S. Frey and Susanne Neckermann, Awards in Economics - Towards a New Field of Inquiry, January 2009

2516 Gregory Gilpin and Michael Kaganovich, The Quantity and Quality of Teachers: A Dynamic Trade-off, January 2009 
2517 Sascha O. Becker, Peter H. Egger and Valeria Merlo, How Low Business Tax Rates Attract Multinational Headquarters: Municipality-Level Evidence from Germany, January 2009

2518 Geir H. Bjønnes, Steinar Holden, Dagfinn Rime and Haakon O.Aa. Solheim, ,Large’ vs. ,Small' Players: A Closer Look at the Dynamics of Speculative Attacks, January 2009

2519 Jesus Crespo Cuaresma, Gernot Doppelhofer and Martin Feldkircher, The Determinants of Economic Growth in European Regions, January 2009

2520 Salvador Valdés-Prieto, The 2008 Chilean Reform to First-Pillar Pensions, January 2009

2521 Geir B. Asheim and Tapan Mitra, Sustainability and Discounted Utilitarianism in Models of Economic Growth, January 2009

2522 Etienne Farvaque and Gaël Lagadec, Electoral Control when Policies are for Sale, January 2009

2523 Nicholas Barr and Peter Diamond, Reforming Pensions, January 2009

2524 Eric A. Hanushek and Ludger Woessmann, Do Better Schools Lead to More Growth? Cognitive Skills, Economic Outcomes, and Causation, January 2009

2525 Richard Arnott and Eren Inci, The Stability of Downtown Parking and Traffic Congestion, January 2009

2526 John Whalley, Jun Yu and Shunming Zhang, Trade Retaliation in a Monetary-Trade Model, January 2009

2527 Mathias Hoffmann and Thomas Nitschka, Securitization of Mortgage Debt, Asset Prices and International Risk Sharing, January 2009

2528 Steven Brakman and Harry Garretsen, Trade and Geography: Paul Krugman and the 2008 Nobel Prize in Economics, January 2009

2529 Bas Jacobs, Dirk Schindler and Hongyan Yang, Optimal Taxation of Risky Human Capital, January 2009

2530 Annette Alstadsæter and Erik Fjærli, Neutral Taxation of Shareholder Income? Corporate Responses to an Announced Dividend Tax, January 2009

2531 Bruno S. Frey and Susanne Neckermann, Academics Appreciate Awards - A New Aspect of Incentives in Research, January 2009

2532 Nannette Lindenberg and Frank Westermann, Common Trends and Common Cycles among Interest Rates of the G7-Countries, January 2009

2533 Erkki Koskela and Jan König, The Role of Profit Sharing in a Dual Labour Market with Flexible Outsourcing, January 2009 